Estuarine, Coastal and Shelf Science

September 2016, Volume 179, Pages 201-206

http://dx.doi.org/10.1016/i.ecss.2015.10.023

http://archimer.ifremer.fr/doc/00288/39921/

(c) 2015 Elsevier Ltd. All rights reserved.

\title{
Stable isotope ratios in bentho-demersal biota along a depth gradient in the bay of biscay: A multitrophic study
}

\author{
Schaal Gauthier ${ }^{1,{ }^{*}}$, Nerot Caroline ${ }^{1}$, Grall Jacques ${ }^{2}$, Chouvelon Tiphaine ${ }^{1,3,5}$, Lorrain Anne ${ }^{1}$, \\ Mortillaro Jean-Michel ${ }^{2,6}$, Savoye Nicolas ${ }^{4}$, Brind'Amour Anik ${ }^{5}$, Paulet Yves-Marie ${ }^{1}$, Le Bris Hervé ${ }^{6}$
}

${ }^{1}$ Laboratoire des Sciences de l'Environnement Marin, UMR 6539 UBO, CNRS, IRD, Ifremer, Institut Universitaire Européen de la Mer, Rue Dumont d'Urville, 29280, Plouzané, France

2 Observatoire du Domaine Côtier, UMS 3113, Institut Universitaire Européen de la Mer, Rue Dumont d'Urville, 29280, Plouzané, France

${ }^{3}$ UMR 6250, LIENSs, Université de la Rochelle, Bât. Marie Curie, Rue Paul-Emile Victor, 17000, La

Rochelle, France

${ }^{4}$ Laboratoire EPOC, UMR 5805 Université de Bordeaux I, CNRS, Station Marine d'Arcachon, 2 Rue du Professeur Jolyet, 33120, Arcachon, France

${ }^{5}$ Unité Ecologie et Modèles pour l'Halieutique, Ifremer, BP21105, Rue de l'lle d'Yeu, 44311, Nantes Cedex 03, France

${ }^{6}$ Agrocampus Ouest, UMR 985 Ecologie et Santé des Ecosystèmes, CS 84215, 65 Rue de St Brieuc, 35042, Rennes, France

* Corresponding author: Gauthier, Schaal, Tel.: +33 [0] 298498690 ;

email address : Gauthier.Schaal@univ-brest.fr

\begin{abstract}
:
Although stable isotope ratios are increasingly used to investigate the trophic ecology of marine organisms, their spatial variations are still poorly understood in the coastal environment. In this study, we measured the stable isotope composition $(\delta 13 \mathrm{C}, \delta 15 \mathrm{~N})$ of suspended particulate organic matter (SPOM) (primary producer), a suspension feeder, the great scallop Pecten maximus (primary consumer), megabenthic decapods and benthic fishes (secondary consumers) along a depth gradient (from $5 \mathrm{~m}$ to $155 \mathrm{~m}$ depth) across the continental shelf of the Bay of Biscay. Although the three trophic levels exhibited similar $\delta 13 \mathrm{C}$ patterns along the gradient, the $\delta 15 \mathrm{~N}$ patterns varied between SPOM, scallops and carnivores. The $\delta 15 \mathrm{~N}$ difference between SPOM and scallops decreased with increasing depth, suggesting that non trophic factors may affect the stable isotope composition of scallops at deepest sampling stations. An opposed trend was found between scallops and carnivores, suggesting that the trophic level of these carnivores increased at higher depth, possibly as an adaptation to lower prey abundances. Although our results suggest that primary consumers are suitable to establish isotopic baselines in coastal environments, we stress the need for further studies aiming at characterizing the variability of stable isotopes in coastal biota, and the respective effects of baseline, trophic and metabolic factors in their isotopic composition.
\end{abstract}

Keywords : trophic, coastal, bivalves, food web, Bay of Biscay 
42

Coastal ecosystems are interface zones that receive high nutrient and particulate inputs of both continental and marine origin. Consequently, these areas are characterized by strong environmental gradients that can deeply impact the ecology of their associated organisms. In particular, the reliance of coastal suspension-feeders on continental versus marine suspended particles has been investigated using stable isotopes in several studies over the last twenty years (e.g. Riera and Richard 1996;

Darnaude et al. 2004; Nerot et al. 2012; Marchais et al. 2013). Because particulate material brought to the ocean by rivers is typically ${ }^{13} \mathrm{C}$-depleted (around -28\%o, Peterson and Fry 1987) it contrasts with ${ }^{13} \mathrm{C}$-enriched coastal primary producers (i.e. microphytobenthos, kelps, seagrasses, around $-14 \%$ ) and marine phytoplankton (around $-22 \%$ o). Besides, $\delta^{15} \mathrm{~N}$ values of particulate material at the vicinity of the coastline may display ${ }^{15} \mathrm{~N}$-enriched values associated with the discharge of wastewaters from coastal cities (McClelland et al. 1997; Riera et al. 2000; Costanzo et al. 2001). Because benthic suspensionfeeders directly rely on suspended particulate organic matter (SPOM) for food (Carlier et al. 2007; Le Loc'h et al. 2008), they might be expected to reflect the same isotopic patterns along inshore-offshore gradients: increasing $\delta^{13} \mathrm{C}$ values with decreasing terrestrial particles concentration, then decreasing $\delta^{13} \mathrm{C}$ values with increasing marine phytoplankton abundance. Concerning $\delta^{15} \mathrm{~N}$, a decreasing pattern revealing the dilution of anthropogenic inputs into coastal waters is expected (Chouvelon et al. 2012). Benthic suspension-feeders, such as bivalves, have commonly been used to establish isotopic baselines, because they integrate the short term spatial and temporal variability displayed by primary producers (Post 2002; Rigolet et al. 2014). Under the assumption that the trophic structure of the community is maintained across the continental shelf, the isotopic pattern is therefore expected to be reflected in upper trophic levels, provided predators feed locally and to not exhibit significant migration capacities.

In a recent article, such a pattern has been observed in SPOM and bivalves along a depth gradient (from 20m to 220m) of Northeast Atlantic (Nerot et al. 2012). However, although bivalves and SPOM displayed similar $\delta^{13} \mathrm{C}$ patterns with depth, the $\delta^{15} \mathrm{~N}$ decrease along the depth gradient was stronger for bivalves than for SPOM, resulting in bivalves displaying lower $\delta^{15} \mathrm{~N}$ than their supposed food source 
at deepest sampling stations. This could result from the dilution of anthropogenic inputs, but the depth (i.e. 190m) as well as the low freshwater input to the coastal ecosystem in this area (Mortillaro et al. 2014) makes this hypothesis rather unlikely. The alternative hypothesis proposed by Nerot et al. (2012) consists in the influence of metabolic factors that would alter isotopic fractionation between bivalves and their food source. Nerot et al. (2012) called for additional studies investigating this pattern, that is of critical importance, since nitrogen isotopes, that displayed the most intriguing pattern along this gradient, are commonly used to asses trophic level in a variety of marine organisms (e.g. Page et al. 2013). Such confounding factors might result in isotopic approaches being invalid to investigate the diet of benthic consumers at the deepest limit of their distribution range. A possible way to address this issue is to investigate depth-related isotopic patterns in higher trophic level organisms, i.e. predators. If low $\delta^{15} \mathrm{~N}$ observed in bivalves at the edge of the continental reflect metabolic factors, one could expect that these factors would also affect predators' stable isotope composition, which would therefore display a different depth-related isotopic pattern. In contrast, similar isotopic patterns along the depth gradient between primary and secondary consumers would suggest that $\delta^{15} \mathrm{~N}$ patterns reported in scallops were due to diet shifts.

The present study aims at measuring the distribution of carbon and nitrogen stable isotopes in benthic sources (SPOM and sediment organic matter (SOM)) and secondary consumers along a depth gradient across the continental shelf of the Bay of Biscay. The aims were two fold: (1) to explore isotopic variation in SPOM and bivalves along a depth gradient (down to $155 \mathrm{~m}$ depth) in another part of the northern Bay of Biscay than that observed by Nérot et al. (2012) and (2) to investigate whether this pattern was transferred up to higher trophic level organisms, that is, megabenthic decapods and bentho-demersal fishes.

\section{MATERIAL AND METHODS}

This study was carried out in the Northern part of Bay of Biscay, from the Vilaine river estuary down to the limit of the continental shelf (figure 1). The total area of the Vilaine river catchment is $10500 \mathrm{~km}^{2}$, and is characterized by the presence of urban areas (1 million inhabitants in the 
catchment) and intensive farming (cereals, cattle and poultry), whose effluents can affect the nature of inputs brought to the oceans by the river. Animal samples were collected in June 2010 using a beam trawl (2.9m wide and $0.5 \mathrm{~m}$ high opening), an otter trawl (average $11 \mathrm{~m}$ wide and $2.5 \mathrm{~m}$ high opening) or scallops dredge ( $2 \mathrm{~m}$ wide, $0,5 \mathrm{~m}$ opening). Although we tried as much as possible to collect species representative of primary and secondary consumers that were present all along the depth gradient, this objective was only achieved for the great scallop Pecten maximus. For crustaceans and fish, different species with partial overlap in their depth distributions were sampled along the depth gradient.

Sediment was sampled using a Van Veen grab (only the upper $0.5 \mathrm{~cm}$ were analyzed), and bottom water using a $8 \mathrm{~L}$ Niskin bottle at $1 \mathrm{~m}$ above the bottom.

Animal samples were sorted onboard, and the great scallop Pecten maximus, the decapods Liocarcinus holsatus, Liocarcinus marmoreus, Macropipus tuberculatus, Munida rugosa, and the fish Arnoglossus imperialis, Arnoglossus laterna and Callionymus lyra were collected, measured and weighed (between 3 and ten replicates per station, according to their respective abundances in samples). Their muscles were then dissected and stored frozen $\left(-25^{\circ} \mathrm{C}\right)$ until further processing. In the laboratory, samples were freeze-dried and ground into a fine and homogeneous powder. Around 250 $\mu \mathrm{g}$ of powder was then weighed in tin capsules for isotopic analysis. Because only pure muscle tissues were analyzed, no acidification was performed on animal samples.

Bottom water samples (three replicates per sampling station) were filtered on pre-combusted (4h, $\left.450^{\circ} \mathrm{C}\right) \mathrm{GF} / \mathrm{F}$ filters that were briefly acidified, rinsed with distilled water, oven-dried $\left(60^{\circ} \mathrm{C}, 48 \mathrm{~h}\right)$, folded and placed into tin capsules. Surface sediment was freeze-dried, sieved ( $500 \mu \mathrm{m}$ mesh), the fine fraction was ground into powder while larger particles were discarded. For C isotopic composition, sediment powder was weighed in silver cups and decarbonated using $\mathrm{HCl}(1.2 \mathrm{~N})$. For $\mathrm{N}$ isotopic composition, the bulk sample (i.e. not acidified) was analyzed.

Bivalves were analyzed at the Stable Isotopes in Nature Laboratory (New Brunswick, Canada) on a Costech 4010 elemental analyzer coupled to either a Finnigan Delta Plus or a Finnigan Delta Plus XP mass spectrometer. SPOM, SOM and predators (both crabs and fish) were analyzed at the LIENSs laboratory (La Rochelle, France) using a Thermo Scientific Flash EA1112 elemental analyzer coupled to a Delta V Advantage mass spectrometer. Results are expressed in standard $\delta$ notation based on 
125

international standards (Vienna Pee Dee Belemnite for $\delta^{13} \mathrm{C}$ and $\mathrm{N} 2$ for $\delta^{15} \mathrm{~N}$ ) following the equation $\delta^{13} \mathrm{C}$ or $\delta^{15} \mathrm{~N}=\left[\left(\mathrm{R}_{\text {sample }} / \mathrm{R}_{\text {standard }}\right)-1\right] \times 10^{3}$ (in \%o) where $\mathrm{R}$ is ${ }^{13} \mathrm{C} /{ }^{12} \mathrm{C}$ or ${ }^{15} \mathrm{~N} /{ }^{14} \mathrm{~N}$.

The effects of depth on stable isotope ratios were assessed through linear regressions. In order to compare isotopic trends displayed by the different biota sampled, regression slopes were compared by means of ANCOVAs, using taxa as a categorical variable.

\section{RESULTS}

Stable isotope ratios measured for bottom suspended particulate organic matter (SPOM) in the Vilaine river displayed typically ${ }^{13} \mathrm{C}$ depleted $($ means \pm standard deviations $=-31.1 \pm 2.1 \%$, respectively) and ${ }^{15} \mathrm{~N}$ enriched values $\left(13.8 \pm 3.0 \%\right.$ ) (Figure 2). SPOM $\delta^{13} \mathrm{C}$ decreased along the gradient, from $-19.9 \pm 0.3 \%$ at the most shallow station down to $-23.9 \pm 0.4 \%$ at the deepest station (155m depth) (figure 2). The $\delta^{15} \mathrm{~N}$ decreased from ca. $11.5 \%$ upstream the Vilaine estuary down to $6.4 \pm 0.4 \%$ at the deepest station. In contrast with SPOM, the $\delta^{13} \mathrm{C}$ of SOM did not display any obvious trend, and experienced high variability along the depth gradient (Table 1). In contrast, SOM $\delta^{15} \mathrm{~N}$ decreased with depth, from $7.7 \pm 0.6 \%$ o for shallow stations down to $6.3 \pm 0.3 \%$ o for the deepest sampling station.

The $\delta^{13} \mathrm{C}$ of the suspension-feeder Pecten maximus decreased along the depth gradient, nearshore stations being slightly ${ }^{13} \mathrm{C}$ enriched (between $-17.3 \%$ and $-15.5 \%$ ) compared to offshore stations (between $-18.3 \%$ and $-17.1 \%$ o)(figure 2). No significant difference could be found between the slopes of SPOM and P. maximus for $\delta^{13} \mathrm{C}$ (ANCOVA, $\mathrm{F}=0.587, \mathrm{p}=0.45$ ). The $\delta^{15} \mathrm{~N}$ of $P$. maximus displayed a marked ${ }^{15} \mathrm{~N}$ depletion trend along the depth gradient, from $9.5 \pm 0.2 \%$ at $22 \mathrm{~m}$ depth down to $4.0 \% ₫ \pm 0.3 \%$ for the deepest sampling station and differed from the trends exhibited by SPOM (ANCOVA, F=23.74, $\mathrm{p}<0.001$ ). Consequently, scallops sampled at more than $140 \mathrm{~m}$ were ${ }^{15} \mathrm{~N}$ depleted compared SOM and SPOM values.

Secondary consumers were grouped in two taxo-functional groups for the analysis: predatory decapods (Macropipus tuberculatus, Munida rugosa., Liocarcinus sp.) and benthic fishes 
153

154

155

156

157

158

159

160

161

162

163

164

165

166

167

168

169

170

171

172

173

174

175

176

177

178

179

(Arnoglossus spp., Callionymus lyra). Both $\delta^{13} \mathrm{C}$ and $\delta^{15} \mathrm{~N}$ decreased along the depth gradient for these two taxo-functional groups (figure 3, table 2). However, although these two groups displayed the same $\delta^{13} \mathrm{C}$ gradient along the depth gradient (ANCOVA, $\mathrm{F}=1.168, \mathrm{p}=0.28$ ), their $\delta^{15} \mathrm{~N}$ varied differently, the slope being steeper for decapods than for fishes (ANCOVA, F=38.01, $\mathrm{p}<0.001$ ). Isotopic trends displayed by both groups differed from the one displayed by Pecten maximus, for both $\delta^{13} \mathrm{C}$ (ANCOVAs, $\mathrm{F}=30.7, \mathrm{p}<0.001$ and $\mathrm{F}=4.7, \mathrm{p}=0.032$ for fish and crustaceans, respectively) and $\delta^{15} \mathrm{~N}$ (ANCOVAs, $\mathrm{F}=1286.6, \mathrm{p}<0.001$ and $\mathrm{F}=773.0$, $\mathrm{p}<0.001$ for fish and crustaceans, respectively). Among the different predator species sampled, Munida rugosa departed through lower $\delta^{15} \mathrm{~N}$ and higher $\delta^{13} \mathrm{C}$ values, while the different depth ranges made it difficult to robustly identify consistent patterns at the species level. Besides, the two Arnoglossus fish were consistently the most ${ }^{15} \mathrm{~N}$-enriched of cooccurring carnivores, but did not display any specific $\delta^{13} \mathrm{C}$ pattern.

\section{DISCUSSION}

Stable isotope analysis has become over the last twenty years a popular tool to investigate the diet of marine consumers, including consumers sampled along depth gradients on continental shelves (e.g. Kline 2009; Chouvelon et al. 2012; Nerot et al. 2012). This method is based on different assumptions, among which the need to accurately know the fractionation occurring between a consumer and its prey (Gannes et al. 1998). In marine soft-bottom ecosystems, most consumers rely on composite food sources (e.g. SPOM, SOM), whose isolation of "pure" components is technically impossible, making it challenging to characterize trophic fractionations, and then, trophic relationships. An alternative option to characterize these relationships is the spatial analysis of both consumers and their potential sources, under the assumption that co-varying sources and consumers are likely to be linked by a trophic relationship (Melville and Connolly 2003; Vanderklift and Wernberg 2010, Leclerc et al. 2013). 
A marked $\delta^{13} \mathrm{C}$ difference $(\approx 4 \%$ ) was observed between SPOM and $P$. maximus all along the

depth gradient. Although this difference seems at odd with a direct trophic relationship between scallops and SPOM, it has been repeatedly reported from various sublittoral ecosystems (e.g. Hobson et al. 1995; Grall et al. 2006; Carlier et al. 2007; Le Loc'h et al. 2008). Different interpretations have been proposed to explain this difference, including abnormal isotopic fractionation (including tissuespecific isotopic fractionation), local variability in phytoplankton stable isotope composition, selective feeding, or contribution of other sources (see Miller and Page 2012; Leclerc et al. 2013). In the present study, the two food sources available to scallops, SPOM and SOM, are both ${ }^{13} \mathrm{C}$ depleted compared to P. maximus, suggesting that the ${ }^{13} \mathrm{C}$ enriched isotopic ratios displayed by this bivalve arise from a selective assimilation of a ${ }^{13} \mathrm{C}$ enriched fraction of SPOM (see Carlier et al. 2007 for instance) or from an unexpectedly high carbon isotopic fractionation. For instance, a $\delta^{13} \mathrm{C}$ fractionation of $3.5 \%$ has been experimentally determined between phytoplankton and the clam Ruditapes philippinarum (Dang et al. (2009). Another explanation for this $\delta^{13} \mathrm{C}$ difference between POM, SOM and primary consumers is the contribution of freshwater originating, ${ }^{13} \mathrm{C}$-depleted particles, that would not be assimilated by suspension-feeders, This explanation is however very unlikely for most sampling sites (excepted the most inshore). The sampling period (early summer) corresponds to the smallest extent of the Loire river plume, that is, anyway, restricted to the first meters of the water column (Lunven et al. 2005). It is therefore unlikely that isotopic patterns observed in the present study reflect the influence of freshwater inputs. In any event, the consistency of this isotopic difference between SPOM and $P$. maximus along the depth gradient would suggest that the diet of scallops does not drastically change between shallow and deeper areas.

In a recent article, Nerot et al. (2012) observed that the $\delta^{15} \mathrm{~N}$ of suspension-feeders and SPOM did not evolve similarly along a depth gradient, suggesting a diet shift along this gradient or a modification in the trophic fractionation with increasing depth. An important finding of the present study is a new observation in northern Bay of Biscay of the $\delta^{15} \mathrm{~N}$ decreasing pattern observed in scallops, the slope of this trend being steeper than for their supposed food source. This new observation suggests that this is common along the continental shelf, as reported for other areas of the Bay of Biscay (Chouvelon et al. 2012) or in northern Pacific (Kline 2009). It has recently been 
suggested, based on fatty acid composition of $P$. maximus digestive gland, that the diet of scallops differed between shallow and deeper sites, including a lower reliance on fresh phytoplankton and the assimilation of degraded material as well as the different components of the microbial food web for the deepest sampling stations (Nerot et al. in press). In our study, this hypothesis would involve that SPOM at deepest sites is mostly composed of refractory ${ }^{15} \mathrm{~N}$ enriched material, and that primary consumers only assimilate a minor ${ }^{15} \mathrm{~N}$ depleted fraction, resulting in the difference between the isotopic composition of SPOM and bivalves food source. Such a ${ }^{15} \mathrm{~N}$ depleted fraction could be represented by degraded material, which is more readily available to consumers (Tenore et al. 1983). However, degradation processes are known to cause an increase in the $\delta^{15} \mathrm{~N}$ of phytoplankton (e.g. Montoya et al. 1992), while in the present study scallops seem to rely on $a^{15} \mathrm{~N}$ depleted source. Such an heterogeneity in the isotopic composition of fractions that compose the pool of SPOM has already been shown among microalgae in freshwater lakes (Vuorio et al. 2004) or among cultured marine microalgae (Falkowski 1991). However, in the present study, similarities in the $\delta^{13} \mathrm{C}$ patterns displayed by SPOM, Pecten maximus, carnivorous decapods and benthic fishes along the depth gradient suggest that no drastic diet shift occurs. Hence, our results suggest that discrepancies observed in the $\delta^{15} \mathrm{~N}$ of biota sampled on the continental shelf of the Bay of Biscay arise, at least mainly, from variability in nitrogen trophic fractionation between primary consumers and their food sources. Indeed, different studies aiming to characterize factors affecting isotopic trophic-step fractionation found that temperature, food availability or nutrient levels were likely to significantly affect the value of this fractionation (e.g. Moeri et al. 2003; Aberle and Malzahn 2007; Bloomfield et al. 2011). For instance the lower $\delta^{15} \mathrm{~N}$ fractionation observed in detritivores compared to herbivores $(0.53 \%$ vs $2.98 \%$, respectively, Vanderklift and Ponsard 2003) might contribute to the low values observed in deepest scallops, that have been reported to rely on recycled material (Nerot et al. in press). The metabolism of scallops is therefore probably affected by these different factors at deeper sampling stations, resulting in a modified trophic-step fractionation. Although laboratory and modelling studies have shown in past an effect of metabolic condition on isotopic fractionation (e.g. Hobson and Clark 1992; Emmery et al. 2011), it had rarely been noticed from field studies. For stable isotope studies carried out over environmental gradients, possibly encompassing optimal and sub-optimal ecological conditions, this 
variability can strongly affect the outcomes of trophic inferences. The results from these studies must therefore be analyzed with much care before conclusions could be drawn about the trophic ecology of consumers.

\section{Depth-related isotopic patterns in carnivores}

Demersal fish, such as the dragonet Callionymus lyra or the scaldfish Arnoglossus spp., as well as megabenthic decapods sampled for this study, are known to feed mainly on small invertebrates or fish juveniles (Deniel 1975; Choi 1986; Abello 1989). Stable isotope ratios measured in the different bentho-demersal carnivores were in accordance with a diet mainly based on local primary consumers for the most shallow sampling stations, being ${ }^{15} \mathrm{~N}$ enriched of 2-4\% compared to scallops (Vander Zanden and Rasmussen 2001). Although the carnivores sampled in this study are unlikely to actually feed on scallops because of their large size, this suggests that these suspension-feeders are good estimators of average primary consumers $\delta^{15} \mathrm{~N}$, hence being potentially reliable to establish isotopic baselines. However, the $\delta^{15} \mathrm{~N}$ difference between those carnivores and scallops increased with increasing depth (Figure 4), in opposition to what was observed between SPOM and scallops. Lower feeding levels for carnivores at higher depth could cause increased trophic enrichment factors that could explain the differences in $\delta^{15} \mathrm{~N}$ trends observed for scallops and carnivores along the depth gradient. It has for instance been reported that the feeding level could modify by more than $2 \%$ o the fractionation between a consumer and its food source (Emmery et al. 2011). The basal trophic resource of shelf benthic communities is a mixture of resuspended sediment and sinking phytoplankton (Carlier et al. 2007; Le Loc'h et al. 2008), whose abundance decreases with increasing depth. Hence, deep benthic communities are sustained by a lower abundance of organic matter, and are therefore less abundant (personal observation). If feeding levels were the main reason for the observed modification of isotopic fractionation with depth, this should therefore be observed for both primary and secondary consumers. The fact that isotopic fractionation displays an opposite pattern with depth for primary and secondary consumers suggests that this is not the case in northern Bay of Biscay. An alternative explanation for the higher $\delta^{15} \mathrm{~N}$ difference between scallops and carnivores at higher depth involves an increase in the trophic level of those carnivores with increasing depth. All the carnivores sampled for 
this study are known to feed on a wide array on vertebrate and invertebrate preys, including shrimps or small fish, which are themselves carnivores (Deniel 1975; Choi 1986; Abello 1989). The low density of potential prey on the deep continental shelf could lead them to rely on higher trophic level prey, explaining higher $\delta^{15} \mathrm{~N}$ than those expected for strict secondary consumers.

Although this pattern is shared by all the carnivores considered, it seems that the squat lobster Munida rugosa feeds at a slightly lower trophic level than others, because its $\delta^{15} \mathrm{~N}$ is consistently lower. Although M. rugosa is generally considered as a strict carnivore (Le Loc'h \& Hily 2005), it is possible that this species feed at a slightly lower trophic level than other decapods. In particular, this species has been reported to be able to rely on sedimented planktonic particles, which would explain the lower trophic level observed here (Lagardère 1973). In contrast, the two Arnoglossus species display the highest $\delta^{15} \mathrm{~N}$ of co-occurring carnivores, which could result from a slightly higher trophic level.

\section{CONCLUSION}

Although it was impossible, for logistical reasons, to repeat this sampling in time in order to assess the seasonal variability of the patterns described here, we are quite confident that they may be valid for larger time scales. Indeed, not only tissues (i.e. muscles) sampled in this study integrate dietary information over long periods (several months for fish, see Perga and Gerdeaux 2005) but offshore ecosystems are less temporally variable ecosystems than nearshore ones. No significant influence of freshwater inputs on the benthos was observed in this study. Northward coastal currents in this area of the Bay of Biscay result in these inputs being transferred to the open ocean along the southern coast of Brittany. The continental shelf of the Northern Bay of Biscay is therefore under limited freshwater influence. Identifying the spatial variability of basal trophic resources isotopic composition is necessary in any isotopic study including a spatial perspective. In this study, the differences in the depth-related isotopic patterns displayed by the different trophic levels suggest that the use of primary consumers as proxies for ecological mechanisms occurring on the continental shelf may not be valid for the entire bentho-demersal community. Although metabolic factors that can 
292 contribute to this lag are difficult to untangle from baseline or trophic effects, it seems necessary to

293 seriously consider them for the interpretation of stable isotope results in future studies. The authors would like to thank the crew of the N/O "Gwen Drez", as well as SINLAB and G.

297 Guillou, from LIENSs laboratory for isotopic analyses. This work was financially supported by the 298 EC2CO program ISOBENT and by the GIS Europôle Mer. GS is supported by the 'Laboratoire 299 d'Excellence' LabexMER (ANR-10-LABX-19), funded by a grant from the French government under 300 the program 'Investissements d'Avenir'. The $\mathrm{PhD}$ fellowship of $\mathrm{C}$. Nerot was funded by the Région 301 Bretagne. 
Abello P., 1989. Feeding habits of Macropipus tuberculatus (Brachyura, Portunidae) off the catalan coast (NW Mediterranean). Miscellania Zoologica 13, 45-50.

Aberle N., Malzahn A.M., 2007. Interspecific and nutrient-dependant variations in stable isotope fractionation: experimental studies simulating pelagic multitrophic systems. Oecologia 154, 291-303.

Bloomfield A.J., Elsdon T.S., Walther B.D., Gier E.J., Gillanders B.M., 2011. Temperature and diet affect carbon and nitrogen isotopes of fish muscle: can amino acid nitrogen isotopes explain effects? Journal of Experimental Marine Biology and Ecology 399, 48-59.

Carlier A., Riera P., Amouroux J., Bodiou J., Grémare A., 2007. Benthic trophic network in the Bay of Banyuls sur Mer (northwest Maditerranean, France): an assessment based on stable carbon and nitrogen isotopes analysis. Estuarine, Coastal and Shelf Science 72, 1-15.

Choi S.C., 1986. Natural diet and feeding habits of the crabs Liocarcinus puber and L. holsatus (Decapoda, Brachyura, Portunidae). Marine Ecology Progress Series 31, 87-99.

Chouvelon T., Spitz J., Caurant F., Mèndez-Fernandez P., Chappuis A., Laugier F., Le Goff E., Bustamante P., 2012. Revisiting the use of $\delta^{15} \mathrm{~N}$ in meso-scale studies of marine food webs by considering spatio-temporal variations in stable isotopic signatures - The case of an open ecosystem: the Bay of Biscay (North-East Atlantic). Progress in Oceanography 101, 92-105.

Costanzo S.D., O’Donoghue M.J., Dennison W.C., Loneragan N.R., Thomas M., 2001. A new approach for detecting and mapping sewage impacts. Marine Pollution Bulletin 42, 149-156.

Dang C., Sauriau P.-G., Savoye N., Caill-Milly N., Martinez P., Millaret C., Haure J., de Montaudouin X., 2009. Determination of diet in Manila clams by spatial analysis of stable isotopes. Marine Ecology Progress Series 387, 167-177.

Darnaude A.M., Salen-Picard C., Harmelin-Vivien M.L., 2004. Depth variation in terrestrial particulate organic matter exploitation by marine coastal benthic communities off the Rhone River delta (NW Mediterrean). Marine Ecology Progress Series 275, 47-57.

Deniel C., 1975. Régimes alimentaires d'Arnoglossus thori Kyle et d'Arnoglossus imperialis Rafinesque (Teleosteens - Bothidae) en Baie de Douarnenez. Revue des Travaux de l'Institut des Pêches Maritimes 38, 105-116.

Emmery A., Lefebvre S., Alunno-Bruscia M., Kooijman S.A.L.M., 2011. Understanding the dynamics of $\delta^{13} \mathrm{C}$ and $\delta^{15} \mathrm{~N}$ in soft tissues of the bivalve Crassostrea gigas facing environmental fluctuations in the context of Dynamic Energy Budget (DEB). Journal of Sea Research 66, 361371.

Falkowski P.G., 1991. Species variability in the fractionation of ${ }^{13} \mathrm{C}$ and ${ }^{12} \mathrm{C}$ by marine phytoplankton. Journal of Plankton Research 13(Suppl), 21-28. 
Gannes L.Z., O'Brien D.M., Martínez del Rio C., 1998. Stable isotopes in animal ecology: assumptions, caveats, and a call for more laboratory experiments. Ecology 78, 1271-1276.

Grall J., Le Loc'h F., Guyonnet B., Riera P., 2006. Community structure and food web based on stable isotopes $\left(\delta^{15} \mathrm{~N}\right.$ and $\left.\delta^{13} \mathrm{C}\right)$ analysis of a North Eastern Atlantic maerl bed. Journal of Experimental Marine Biology and Ecology 338, 1-15.

Hobson K.A., Clark R.G., 1992. Assessing avian diets using stable isotopes II: Factors influencing diet-tissue fractionation. Condor 94, 189-197.

Hobson K.A., Ambrose W.G.Jr., Renaud P.E., 1995? Sources of primary production, benthic-pelagic coupling, and trophic relationships within the Northeast Water Polynia: insights from $\delta^{13} \mathrm{C}$ and $\delta^{15} \mathrm{~N}$ analysis. Marine Ecology Progress Series 128, 1-10.

Kline T.C.Jr., 2009. Characterization of carbon and nitrogen stable isotope gradients in the northern Gulf of Alaska using terminal feed stage copepodite-V Neocalanus cristatus. Deep Sea Research II 56, 2537-2552.

Lagardère J-P., 1973. Distribution des décapodes dans le sud du Golfe de Gascogne. Revue des Travaux de l'Institut des Pêches Maritimes 37, 77-95.

Le Loc'h F., Hily C., 2005. Stable carbon and nitrogen isotope analysis of Nephrops norvegicus / Merluccius merluccius fishing grounds in the Bay of Biscay (Northeast Atlantic). Canadian Journal of Fisheries and Aquatic Sciences 62, 123-132.

Le Loc'h F., Hily C., Grall J., 2008. Benthic community and food web structure on the continental shelf of the Bay of Biscay (North Eastern Atlantic) revealed by stable isotope analysis. Journal of Marine Systems 72, 17-34.

Leclerc J.-C., Riera P., Leroux C., Lévêque L., Laurans M., Schaal G., Davoult D., 2013. Trophic significance of kelps in kelp communities in Brittany (France) inferred from isotopic comparisons. Marine Biology 160, 3249-3258.

Lunven M., Guillaud J.-F., Youénou A., Crassous M.-P., Berric R., Le Gall E., Kérouel R., Labry C., Aminot A., 2005. Nutrient and phytoplankton distribution in the Loire River plume (Bay of Biscay, France) resolved by a new Fine Scale Sampler. Estuarine, Coastal and Shelf Science 65, 94-108.

Marchais V., Schaal G., Grall J., Lorrain A., Nerot C., Richard P., Chauvaud L., 2013. Spatial variability of stable isotope ratios in oysters (Crassostrea gigas) and primary producers along an estuarine gradient (Bay of Brest, France). Estuaries and Coasts 36, 808-819.

McClelland J.W., Valiela I., Michener R.H., 19 97. Nitrogen-stable isotope signature in estuarine food webs: a record of increasing urbanization in coastal watersheds. Limnology and Oceanography 42, 930-937.

Melville A.J., Connolly R.M., 2003. Spatial analysis of stable isotope data to determine primary sources of nutrition for fish. Ocecologia 136, 499-507.

Miller R.J., Page H.M., 2012. Kelp as a trophic resource for marine suspension feeders : a review of isotopes-based evidence. Marine Biology 159, 1391-1402. 
Moeri O., Sternberg L.D.L., Rodicio L.P., Walsh P.J., 2003. Direct effects of ambient ammonia on the nitrogen isotope ratios of fish tissues. Journal of Experimental Marine Biology and Ecology 282, 61-66.

Montoya J.P., Wiebe P.H., McCarthy J.J., 1992. Natural abundance of ${ }^{15} \mathrm{~N}$ in particulate nitrogen and zooplankton in the Gulf Stream region and warm-core ring 86A. Deep Sea Research Part A Oceanographic Research 39, S363-S392.

Mortillaro J.-M., Schaal G., Grall J., Nerot C., Brind'Amour A., Marchais V., Perdriau M., Le Bris H., 2014. Comparative study of isotopic trends in two coastal ecosystems of North Biscay: a multitrophic spatial gradient approach. Estuarine, Coastal and Shelf Science, 136 : 149-156

Nerot C., Lorrain A., Grall J., Gillikin D.P., Munaron J.-M., Le Bris H., Paulet Y.-M., 2012. Stable isotope variations in benthic filter feeders across a large depth gradient on the continental shelf. Estuarine, Coastal and Shelf Science 96, 228-235.

Nerot C., Méziane T., Schaal G., Grall J., Lorrain A., Paulet Y.-M., Kraffe E., in revision. Spatial changes in fatty acids signatures of the great scallop Pecten maximus across the Bay of Biscay continental shelf. Submitted to Journal of Experimental Marine Biology and Ecology.

Page H.M., Brooks A.J., Kulbicki M., Galzin R., Miller R.J., Reed D.C., Schmitt R.J., Holbrook S.J., Koenig C., 2013. Stable isotopes reveal trophic relationships and diet of consumers in temperate kelp forest and coral reef ecosystems. Oceanography 26, 180-189.

Perga M.E., Gerdeaux D., 2005. 'Are fish what they eat' all year round ? Oecologia 144, 598-606.

Peterson B., Fry B., 1987. Stable isotopes in ecological studies. Annual Review of Ecology and Systematics 18, 293-320.

Post D.M., 2002. Using stable isotopes to estimate trophic positions: models, methods, and assumptions. Ecology 83, 703-718.

Riera P., Richard P., 1996. Isotopic determination of food sources of Crassostrea gigas along a trophic gradient in the estuarine bay of Marennes-Oléron. Estuarine, Coastal and Shelf Science 42, 347360 .

Riera P., Stal L.J., Nieuwenhuize J., 2000. Heavy $\delta^{15} \mathrm{~N}$ in intertidal benthic algae and invertebrates in the Scheldt estuary (The Netherlands): effects of river nitrogen inputs. Estuarine, Coastal and Shelf Science 51, 365-372.

Rigolet C., Thiébaut E., Dubois S.F., 2014. Food web structure of subtidal benthic muddy habitats : evidence of microphytobenthos contribution supported by an engineer species. Marine Ecology Progress Series 500, 25-41.

Tenore K., 1983. What controls the availability to animals of detritus derived from vascular plants: organic nitrogen or caloric availability? Marine Ecology Progress Series 10, 307-309.

Vander Zanden M.J., Rasmussen J.B., 2001. Variation in $\delta^{15} \mathrm{~N}$ and $\delta^{13} \mathrm{C}$ trophic fractionation: implications for aquatic food web studies. Limnology and Oceanography 46, 2061-2066.

Vanderklift M.A., Ponsard S., 2003. Sources of variation in consumer-diet $\delta^{15} \mathrm{~N}$ enrichment: a metaanalysis. Oecologia 136, 169-182. 
414 Vanderklift M.A., Wernberg T., 2010. Stable isotopes reveal a consistent consumer-diet relationship across hundreds of kilometres. Marine Ecology Progress Series 403, 53-61.

416 Vuorio K., Meili M., Sarvala J., 2004. Taxon-specific variation in the stable isotopic signatures $\left(\delta^{13} \mathrm{C}\right.$ and $\delta^{15} \mathrm{~N}$ ) of lake phytoplankton; Freshwater Biology 51, 807-822. 


\section{ACCEPTED MANUSCRIPT}

419 Table 1 : linear regressions between depth and stable isotope composition in Pecten maximus, benthic

420 fishes and predatory decapods along a depth gradient in the Northern Bay of Biscay

421

422

\begin{tabular}{llllll}
\hline & & Slope & intercept & p-value & $\mathrm{R}^{2}$ \\
\hline SPOM & $\delta^{13} \mathrm{C}$ & -0.028 & -19.62 & $<0.001$ & 0.76 \\
& $\delta^{15} \mathrm{~N}$ & -0.012 & 9.44 & $<0.001$ & 0.25 \\
SOM & $\delta^{13} \mathrm{C}$ & 0.013 & 24.54 & 0.30 & 0.08 \\
& $\delta^{15} \mathrm{~N}$ & 0.018 & 8.50 & $<0.001$ & 0.55 \\
\multirow{2}{*}{ Pecten maximus } & $\delta^{13} \mathrm{C}$ & -0.010 & -16.00 & $<0.001$ & 0.46 \\
& $\delta^{15} \mathrm{~N}$ & -0.042 & 10.72 & $<0.001$ & 0.95 \\
\hline
\end{tabular}

429

430 
431 Table 2: linear regressions between depth and $\delta^{13} \mathrm{C}$ and $\delta^{15} \mathrm{~N}$ of the different carnivores sampled in this 432 study. Taxa: $\mathrm{F}=$ fish, $\mathrm{C}=$ crustacean.

433

434

Species

$\mathrm{n}$

slope

intercept

$\mathrm{R}^{2} \quad \mathrm{p}$-value

435 Fish

436

Arnoglossus imperialis

$\delta^{13} \mathrm{C} \quad 46 \quad-0.010$

$-16.52$

$0.63<0.001$

437

$\delta^{15} \mathrm{~N} \quad 46 \quad-0.026$

14.61

$0.74<0.001$

438 Arnoglossus laterna

$\delta^{13} \mathrm{C} \quad 14 \quad-0.020$

$-15.32$

$0.76<0.001$

439

$\delta^{15} \mathrm{~N} \quad 14 \quad-0.030$

15.26

$0.83<0.001$

440

Callionymus lyra

$\delta^{13} \mathrm{C} \quad 32 \quad-0.014$

$-16.04$

$0.51<0.001$

441

$\delta^{15} \mathrm{~N} \quad 32 \quad-0.015$

13.172

$0.51<0.001$

\section{Decapods}

\begin{tabular}{llllllll}
443 & Liocarcinus holsatus & $\delta^{13} \mathrm{C}$ & 19 & -0.008 & -16.25 & 0.11 & 0.173 \\
444 & & $\delta^{15} \mathrm{~N}$ & 19 & -0.030 & 14.50 & 0.71 & $<0.001$ \\
445 & Liocarcinus marmoreus & $\delta^{13} \mathrm{C}$ & 21 & -0.0123 & -15.89 & 0.63 & $<0.001$ \\
446 & & $\delta^{15} \mathrm{~N}$ & 21 & -0.016 & 12.93 & 0.52 & $<0.001$ \\
447 & Macropipus tuberculatus & $\delta^{13} \mathrm{C}$ & 19 & -0.017 & -15.59 & 0.39 & 0.004 \\
448 & & $\delta^{15} \mathrm{~N}$ & 19 & -0.043 & 16.12 & 0.33 & 0.010 \\
449 & Munida rugosa & $\delta^{13} \mathrm{C}$ & 25 & -0.014 & -15.20 & 0.42 & $<0.001$ \\
450 & & $\delta^{15} \mathrm{~N}$ & 25 & -0.026 & 13.01 & 0.86 & $<0.001$ \\
\hline
\end{tabular}


452 Figures captions

453 Figure 1:

454 Map of the sampling area in the Northern Bay of Bay. Black dots indicate sampling stations, and the 455 depth is indicated for each station.

$\delta^{13} \mathrm{C}$ and $\delta^{15} \mathrm{~N}$ of suspended particulate organic matter (open circles, large dashes), sediment (open squares, little dashes) and Pecten maximus (black triangles, full line) across the continental shelf of the Bay of Biscay. See table 1 for linear regressions parameters.

Figure 3:

$463 \quad \delta^{13} \mathrm{C}$ and $\delta^{15} \mathrm{~N}$ of the different carnivores sampled across the continental shelf of the Bay of Biscay.

464 For clarity reasons, only regression lines are shown. For linear regression parameters, see table $2.1-$

465 Arnoglossus imperialis, 2- Arnoglossus laterna, 3-Callionymus lyra, 4- Liocarcinus holsatus,

466 5- Liocarcinus marmoreus, 6- Macropipus tuberculatus, 7-Munida rugosa.

467 Figure 4:

468 Relationship between depth and corrected $\delta^{15} \mathrm{~N}\left(\delta^{15} \mathrm{~N}_{\text {carnivore }}-\delta^{15} \mathrm{~N}_{\text {scallops }}\right)$ of demersal fish (dashed line)

469 and megabenthic crustaceans (full line) across the continental shelf of the Bay of Biscay. Fish:

$470 \quad$ corrected $\delta^{15} \mathrm{~N}=0.027 *$ depth $+2.58 ; \mathrm{R}^{2}=0.74 ; \mathrm{p}<0.001$. Crustaceans: corrected $\delta^{15} \mathrm{~N}=0.016 * \mathrm{depth}+2.81$;

471

$\mathrm{R}^{2}=0.45 ; \mathrm{p}<0.001$. 
473 Figure 1:

474

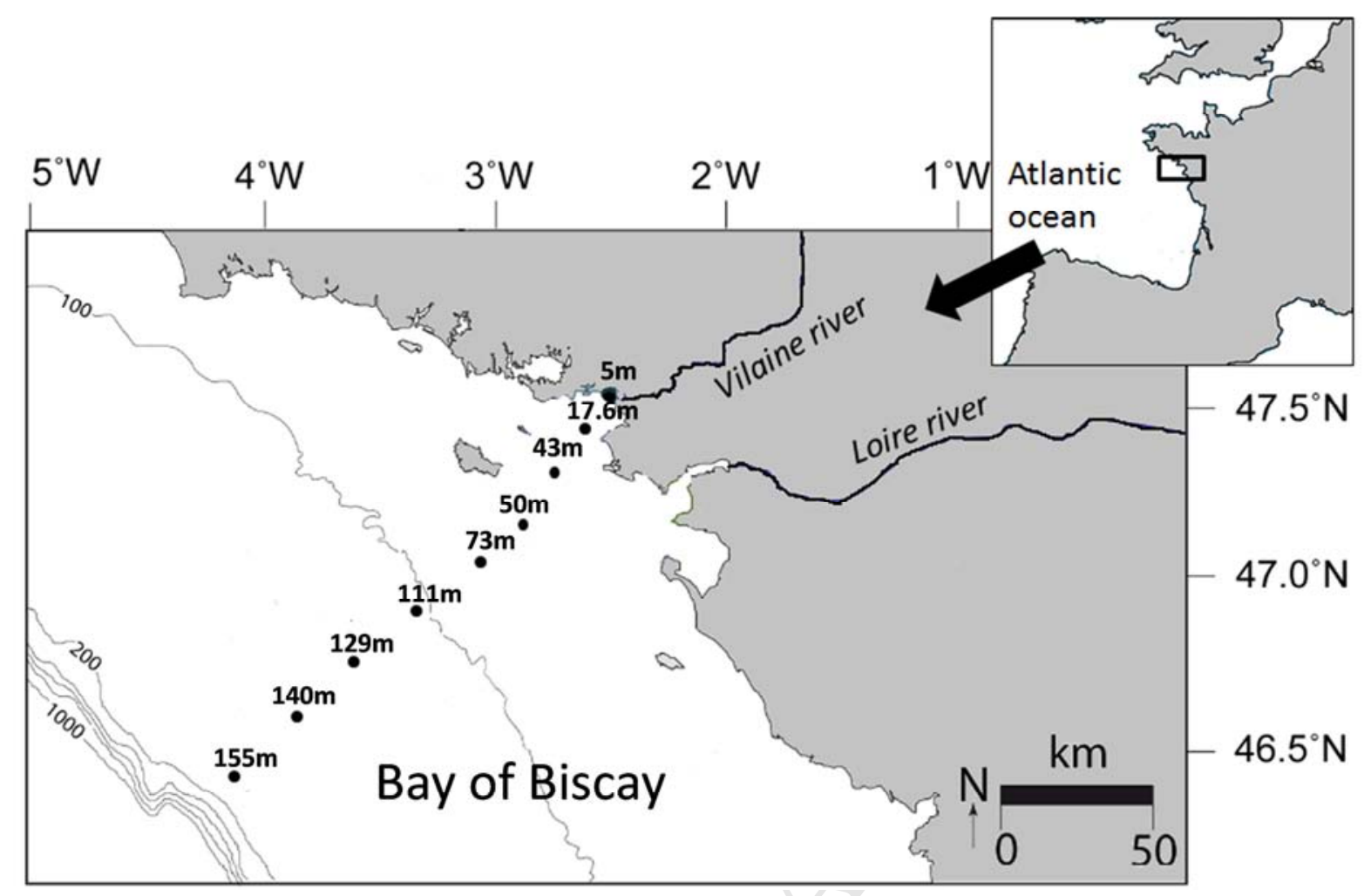

475 Map of the sampling area in the Northern Bay of Bay. Black dots indicate sampling stations, and the 476 depth is indicated for each station. 
Figure 2:
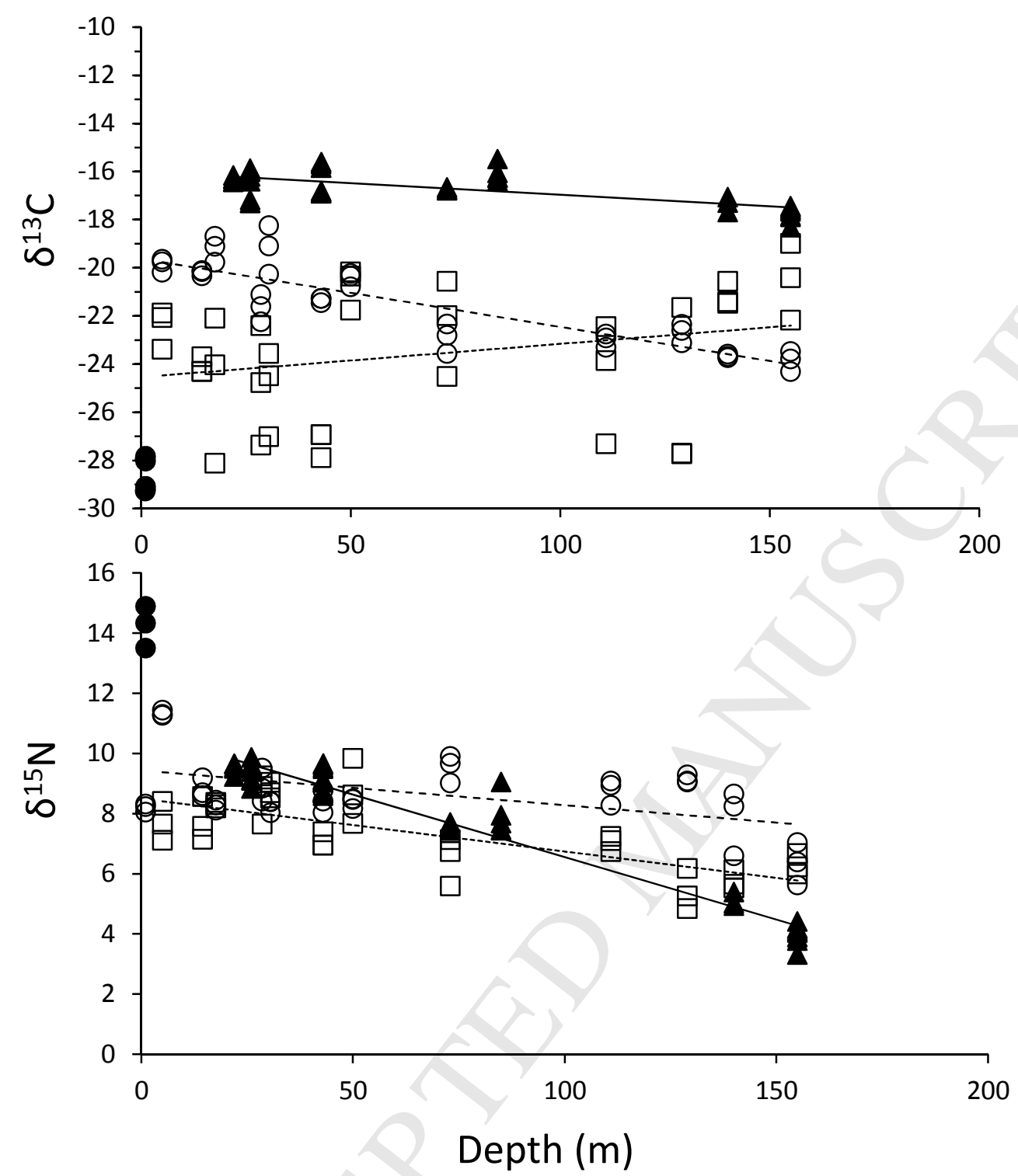

479

$480 \quad \delta^{13} \mathrm{C}$ and $\delta^{15} \mathrm{~N}$ of suspended particulate organic matter (open circles, large dashes), sediment (open 481 squares, little dashes) and Pecten maximus (black triangles, full line) across the continental shelf of the 482 Bay of Biscay. See table 1 for linear regressions parameters. Filled symbols indicates samples from 483 the upper reach of the estuary (salinity $=0$ ) 
Figure 3:
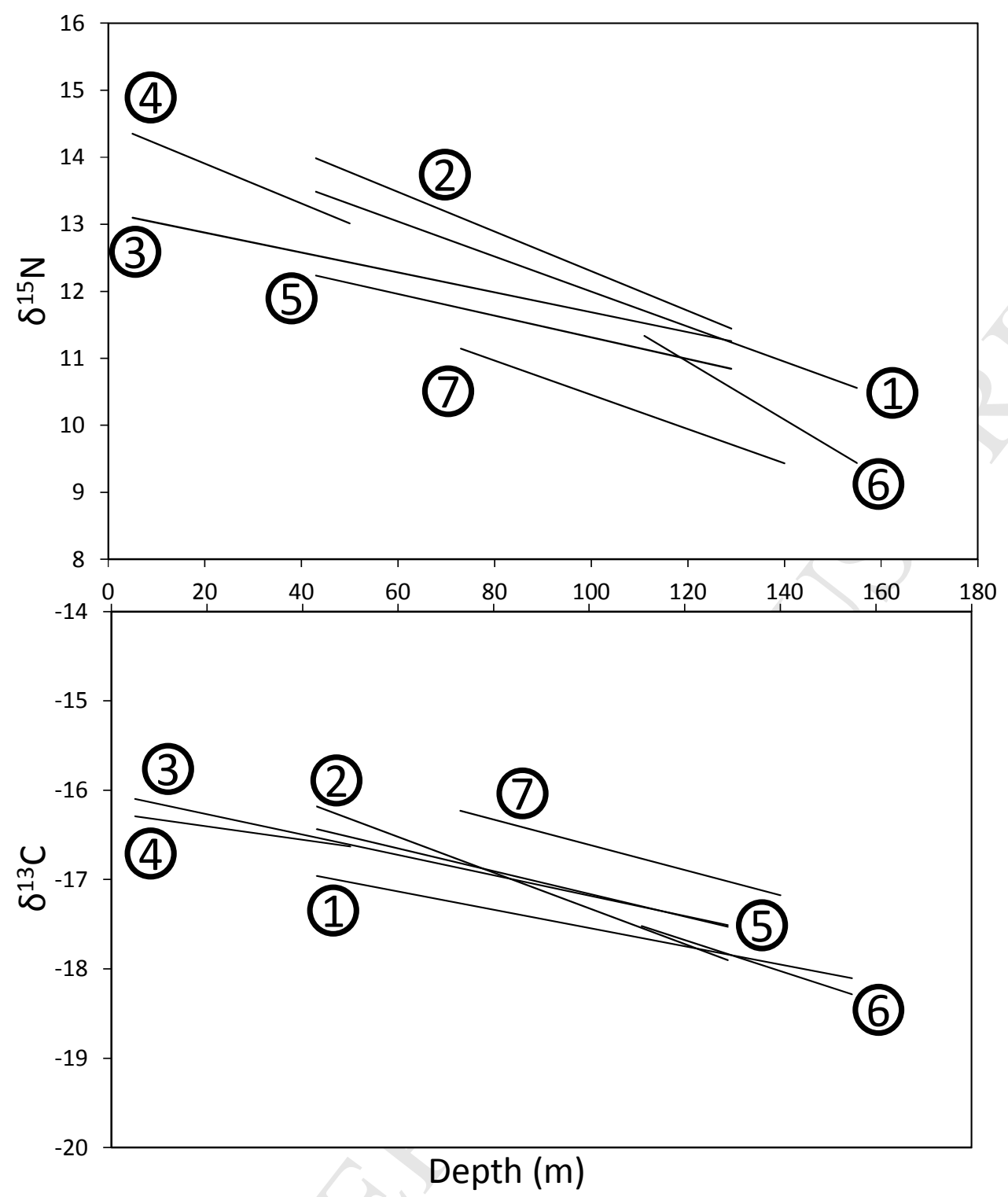

486

$487 \delta^{13} \mathrm{C}$ and $\delta^{15} \mathrm{~N}$ of the different carnivores sampled across the continental shelf of the Bay of Biscay.

488 For clarity reasons, only regression lines are shown. For linear regression parameters, see table 2.

489

490

491 
Figure 4:

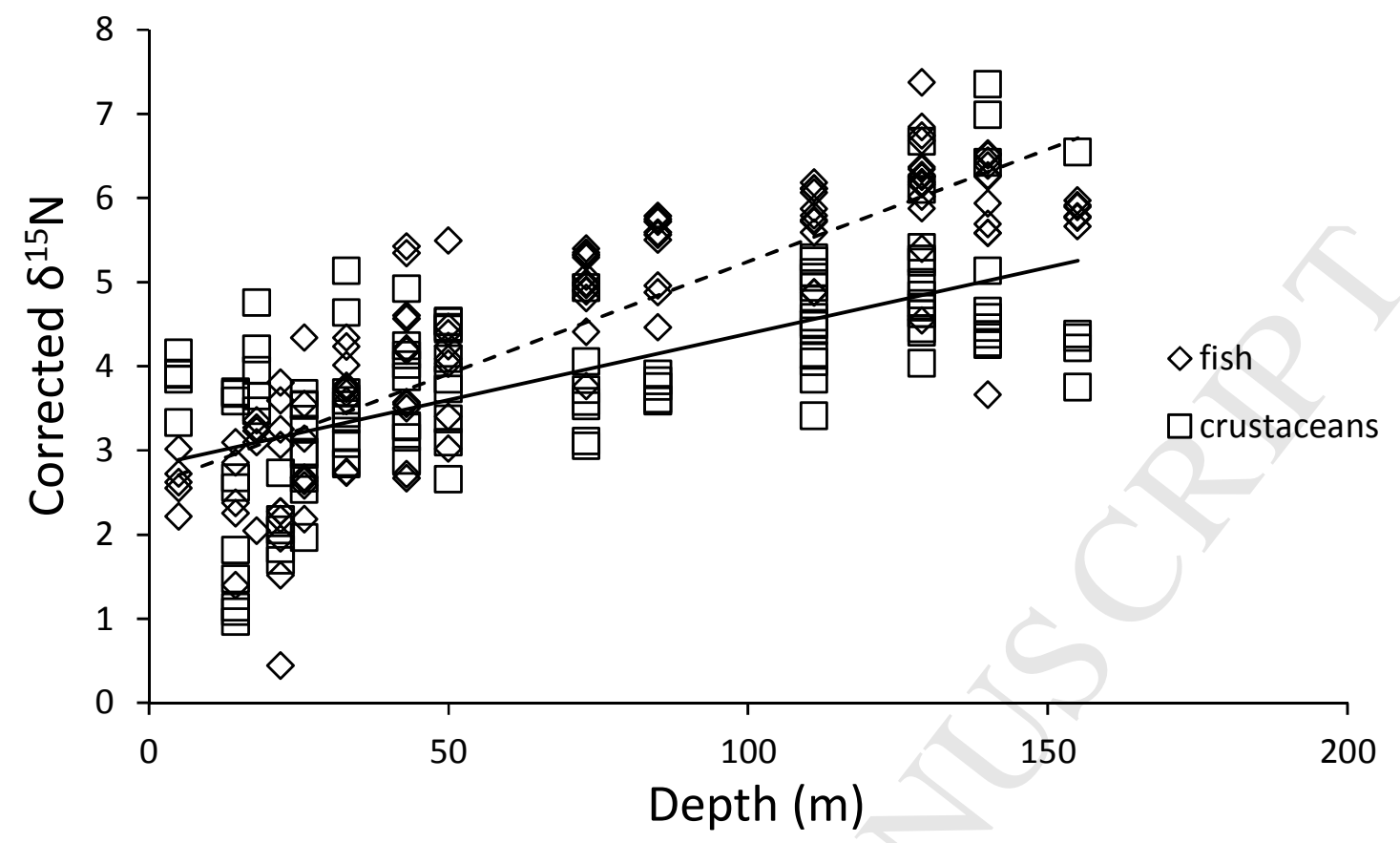

493

494 Relationship between depth and corrected $\delta^{15} \mathrm{~N}\left(\delta^{15} \mathrm{~N}_{\text {carnivore }}-\delta^{15} \mathrm{~N}_{\text {scallops }}\right)$ of demersal fish (dashed line)

495 and megabenthic crustaceans (full line) across the continental shelf of the Bay of Biscay. Fish:

496 corrected $\delta^{15} \mathrm{~N}=0.027 *$ depth $+2.58 ; \mathrm{R}^{2}=0.74 ; \mathrm{p}<0.001$. Crustaceans: corrected $\delta^{15} \mathrm{~N}=0.016 * \mathrm{depth}+2.81$;

$497 \quad \mathrm{R}^{2}=0.45 ; \mathrm{p}<0.001$. 